\section{Fish Otoliths from the Stomach of a Porpoise.}

IN a letter published in NatuRE of December 22, I 923. Dr. Johs. Schmidt of Copenhagen describes the capture of a porpoise off the south coast of Spain, in the stomach of which were found no less than I5, r9I otoliths of fishes. Through the courtesy of Mr. C. Tate Regan, keeper of the zoological department of the Natural History Museum at South Kensington, I have had the opportunity of examining a portion of these otoliths.

They are all sagittæ, saccular otoliths, of which each fish possesses a pair, but as it is highly improbable that these all represent pairs, Dr. Schmidt's estimate of the minimum number of fishes, namely half the number of the otoliths, is conservative, and they probably amount to many more. For example, there are 4 otoliths of Scombresox, of which two form a pair, the other two being unrelated to each other.

The examples submitted number 4338 , of which the great majority, namely 4324 , are from fishes

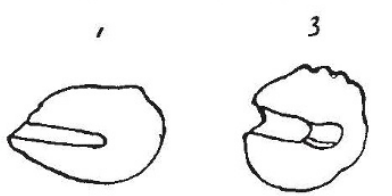
belonging to the Scopelidæ, of which there are 4 species represented. Of the I4 remaining otoliths, 4 are those of Scombresox saurus, allied to the garfishes, and ro may belong to the Macruridæ.

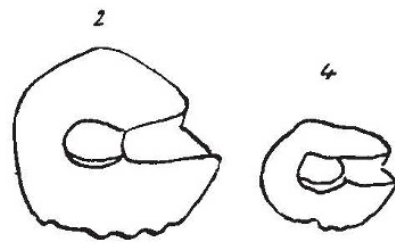
There are no otoliths of Scombroids or Clupeoids.

The characteristics of the six forms of otoliths, of which diagrams are given, are as follows :

(I) Scombresox saurus. 4 examples. Shape of otolith ovate, pointed in front. Sulcus straight, obliquely inclined downwards.

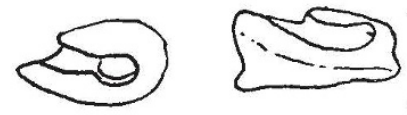

(2) Scopelus sp. 3 examples. A circular otolith with the usual scopeloid sulcus, the upper part of the otolith deeper than the portion below the sulcus, the

(3) Scopelus sp. 2090 examples. Similar to Fig.

Fig. I. - Fish otoliths. (x) Scombresox saurus; (2) Scopelus sp. ; (3) Scopelus sp. ; (4) Siopelus caninianus (5) Scorelus sp. ; (6) Macrurus sp. 2 , but the lower part deeper than the area above the sulcus and not so projecting. The ventral rim is smooth, and there are in some cases serrations on the dorsal edge.

(4) Scopelus caninianus. 2 examples. Shape of otolith ovate, with serrations on ventral rim. Resembles a fossil form from tertiary formations.

(5) Scopelus sp. 2229 examples. This form differs from the last described owing to a frontal extension of the lower part forming a sharply pointed rostrum, the otolith being drop-shaped.

(6) Macrurus? sp. Io examples. Unlike any known otolith, the shape is roughly that of a parallelogram. The sulcus, however, is very similar to a fossil form described by Dr. R. J. Schubert (Jahrb. Geol. Reichsanst., Wien, lv., I905) and referred by him to the Macruridæ; in the absence of any alternative, I therefore refer these forms provisionally to this family as Macrurus ? sp.

The very small otoliths submitted separately are those which have been subjected for a longer time to the gastric juices, the sulcus not being discernible.
The majority of otoliths are from fishes about 4 years old, as shown by the annual rings of growth visible on some of them.

Tubbenden Cottage,

Farnborough, Kent,

February II.

\section{Palæolithic Flakes.}

IN a recent paper (Journ. Roy. Anthrop. Inst., I923) Mr. Reid Moir suggested that Acheulean flakes could be distinguished from Mousterian by differences in certain angles, which he calls the "fracture angle" and the "wing angle" respectively.

Wishing to test this, I examined a number of flakes from the Farnham gravels (Terrace B), which on various grounds I regarded as being Acheulean. It had, indeed, been suggested, from the character of the secondary work, that a few of them might be Mousterian; but the presence of that industry at so high a level seemed improbable, and none of them are of typical Mousterian form.

Some difficulty was experienced with the wing angle, which in a large number of flakes could not be determined satisfactorily; but eventually it was measured in 53 cases, and the fracture angle in 82 cases. The average results were: fracture angle $130^{\circ}$, wing angle $\mathrm{r}_{44^{\circ}}$; and although these do not exactly correspond with any of Mr. Moir's figures, they are far nearer to his Acheulean than to his Mousterian series. The range of variation is high, so that the method is not applicable to single flakes; but the fact that among the fracture angles only three specimens gave as low an angle as Mr. Moir's average for le Moustier $\left(120^{\circ}\right)$ suggests that even for short series valuable indications may be obtainable from this angle alone. I therefore took, at random, five series of five flakes each, and obtained for the fracture angle the following average figures: I29 (twice); I $3 \mathrm{I}^{\circ}$ (twice); I $34^{\circ}$-quite enough, if Mr. Moir's figures are at all correct, to mark even such small groups as Acheulean.

It is much to be hoped that others possessing the necessary material will follow up Mr. Moir's hypothesis. Among other things, I should be interested to know whether the difficulty I experienced with the wing angles may not be a characteristic of the earlier period - the more skilful flaking of later periods leading to more definite and uniform results.

The Gate House, Alumdale Road,

HENRY BURY. Bournemouth West, February 3 .

\section{Consumption of Fish by Porpoises.}

WITH reference to my letter to NATURE of December 22 , p. 902, the following remarks by Dr. R. Legendre, Director of the Zoological Station at Concarneau, France, will be found of interest. Dr. Legendre writes in a letter dated December 27 :

"I have just read your interesting notice in NATURE about the consumption of fish by porpoises. On the coast of Brittany, where I have been able to make a certain number of observations, I never found such a great number of otoliths and eye-lenses of fish, but beaks of Cephalopods and entire Octopus were frequently met with, as I have recently indicated in the Bulletin de la Société Zoologique de France (tome 47, No. 8-9, 1922).

"Does the food of the porpoise vary according to distance from the shore or species encountered ?" 